\title{
Study on the Construction and Management of Teaching Staff in Private Colleges and Universities
}

\author{
Sha Liu ${ }^{1}$, Libing Liu ${ }^{1}$, Biao Yun ${ }^{2}$ \\ ${ }^{1}$ Xi’an Peihua University, Xi’an, Shaanxi, 710125 \\ ${ }^{2}$ Airport Anju Property Co., Ltd., Xi’an, Shaanxi, 712000
}

Keywords: private colleges and universities; teachers; construction; management

\begin{abstract}
In our country, education is an industry that is highly valued. In the education industry, teachers are very important roles. It is very important to ensure the quality of the teaching staff to fundamentally improve teaching quality. Nowadays, private colleges and universities are getting better and better, to strengthen the quality management and construction of the teaching staff, improve the personnel development system, promote the development of competition between talents, and promote the development of the teaching staff in a more rationalized direction. It is the most important thing in current education industry to improve teacher management.
\end{abstract}

\section{Introduction}

With the continuous development of our country's education, private higher education has become the backbone of higher education in our country, and the teachers of private colleges and universities as the main body of school development are the decisive factors in improving the quality of education. How to establish a high-quality teacher team has become a prerequisite for colleges and universities to continuously improve the quality of teaching. It is also a necessary condition for colleges and universities to continue to advance in the development trend.

\section{Composition and Status Quo of Teaching Staff in Private Colleges and Universities}

To improve the quality of education, the first prerequisite is to enhance the quality of teachers and create a team of professional teachers with high quality and high quality. From the perspective of China's development, there are three main components of the teaching staff of private institutions of higher learning: The first is to hire retired professors or experts from public institutions of higher learning. I hope these professors or experts can use their own professional knowledge and The professional experience promotes the improvement of the school's teaching quality; the second is the recruitment of high-quality graduates from the society, through which these outstanding graduates bring about teaching ideas that are closer to the needs of students; the third is from the public schools but can Teachers who work part-time in private schools can not only bring excellent educational resources to private schools, but also help private schools learn the outstanding educational philosophy of public schools. These three parts have become the main sources of teacher resources in the higher private schools in China, and they have contributed their own strength to the development of higher private schools in China.

From the perspective of dialectics, "a coin has two sides," so analyzing the status quo also requires an analysis from two perspectives. From the perspective of development advantages, through the active development of private colleges and universities in recent years, both in terms of scale, talent cultivation, and the construction of teaching staff, have greatly enhanced the degree of social acceptance. The concept of modern people began to slowly change. For private institutions of higher learning, it is not easy to build a very hard teacher team in a very short period of time, breaking the previous state in this regard. However, from the standpoint of development disadvantages, most of the teacher constituents in private institutions of higher learning are served by outside teachers or part-time teachers, and there are relatively few excellent teachers for 
self-cultivation. This has led to the emergence of inadequate teacher preparation in some private schools. The overall quality of teaching is not high, and due to the mobility of part-time teachers, resulting in inconsistent levels of teaching levels, etc., the problem of teachers in private institutions of higher learning is still not solved.

\section{Problems in the Construction of Teacher Ranks in Private Higher Education Institutions}

This problem is mainly reflected in four aspects, namely: the teacher's age structure is not reasonable, the teacher's education and title structure is unreasonable, the teacher's source structure is unreasonable, and the proportion of "dual-qualified" teachers is relatively low. Detailed explanation is as follows:

The teacher's age structure is irrational. This is mainly reflected in the fact that the full-time teachers in private institutions of higher learning have become "anti-cone" distributions with more than two age groups and few in the middle, with the 35-year-old and the 60-year-old as the main dividing lines. Although young teachers under the age of 35 are young, they lack work experience and do not have a good way of summarizing their work methods. There is no way to greatly improve the quality of education for schools. Older teachers over 60 years of age, although they have more work experience and many methods of self-acquisition, due to their age, many senior teachers at this level do not have the energy to come up with new ideas, and many education methods tend to lag behind. . And because the time span of these two age-level teachers is too large, when they are teaching at the same time, collisions are likely to occur, which may lead to contradictions. This is not conducive to the establishment of teacher teams.

The structure of academic qualifications and titles of teachers is irrational. Compared with public institutions, the educational structure of teachers in private institutions of higher learning is mainly graduate students, while the educational structure of teaching staff is mainly undergraduate. In private institutions of higher learning, the proportion of doctoral students is very low. At this point, it loses a lot of advantages over public institutions. In this way, to a certain extent, the starting point for the level of teachers in private colleges and universities is relatively low, so for students, the level of education received will be lower than that of public institutions. This is not only unfavorable for the development of students, but also for the teachers themselves and for the colleges, their development is flawed.

Learning source structure. Private colleges and universities in the teacher hire, the main recruitment are based on the local prefecture-based, or are mainly local schools, many teachers are from a school or a region. This will create a problem in that the teachers' ideas are all very much the same, and there is no integration between what they learn and the outside world. This leads to the possibility that education may not be integrated with the outside world when the students are educated. Can not meet the needs of the outside world.

The percentage of "double-qualified" teachers is relatively low. Since the civilian-run institutions of higher learning are cultivating talents, they mainly focus on innovative talents, solid practical talents, and practical talents with high overall quality. Therefore, for teachers, they need to overcome the students' training goals. . They not only need professional theoretical knowledge, but also need rich practical knowledge. This is a "dual-qualified" teacher. However, for private institutions of higher learning, the threshold is relatively high when teachers are formed, and many skilled craftsmen with rich practical knowledge are unable to enter school because of low academic qualifications. However, the relatively high teachers and employees in schools only pay attention to the study of theoretical knowledge, but they largely ignore the study of practical knowledge. So both are dilemmas. Therefore, from the point of view of social development, this kind of "double-qualified" teacher is very lacking, which is also one of the problems encountered by the construction of the teaching staff.

As far as teacher structure is concerned, the teachers hired by private colleges and universities and the teachers rehired due to their ages may not be able to stand on the podium for teaching for a long time because of various reasons. Many such teachers have only Can teach one to two years. Although young teachers are full of vigor and vitality, the wages and benefits of private institutions 
of higher learning cannot match those of public schools. Therefore, many young teachers will choose more desirable jobs when they encounter better opportunities, resulting in the mobility of young teachers. It is also very large. Part-time teachers do not need to say much more. They can only serve for a period of time and cannot be stable for a long time. Therefore, from this perspective, the overall stability of the teaching staff is relatively poor, which is very unfavorable for the development of the school.

Judging from the general direction of the development of China's education industry, private colleges and universities are relatively short to establish a school, so the atmosphere of scientific research is relatively weak. Although many teachers have a desire to engage in scientific research, due to the insufficient qualifications of private institutions of higher learning, the chances of obtaining research projects are relatively small and the opportunities for participating in academic conferences are very limited. At the starting point lower than others, there are fewer opportunities for development than others. From this point of view, the gap is apparent relative to public institutions.

The optimization of the external environment needs to be carried out in two ways. The first is to change itself, that is, the change of self-concept. There is a need to eliminate the general public's prejudice against private schools. Through the vigorous development in recent years, a large number of school-running ideas have advanced so far, and the scale of schooling is also very large. The quality of teaching is also very high and efficient. However, due to discriminatory concepts, social recognition is not particularly high. Therefore, we need to increase the propaganda of private education, make the prejudice of private education reduce and gradually reduce, and have a relatively objective and correct evaluation of private education. The second is the need to take effective measures to improve the status of teachers in private colleges and universities. To ensure the position of teachers in private colleges and universities not only needs to be protected by law, but also psychologically protected. The government and other relevant departments must take effective measures before they can improve the status of teachers and protect teachers' enjoyment of their own rights. In this way, it can be ensured that the strength of teachers will develop rapidly without being disturbed by external circumstances.

Private colleges and universities need to fully use their own advantages to establish their own development based on the development of the market, so that their own conditions have been continuously improved. Ensure that the school's orientation is clear, and it needs to have very clear development goals, strengthen management, improve school running characteristics, improve the quality of running schools and educating people, and ultimately achieve their own strategic development goals.

\section{Measures to Strengthen the Construction and Management of Teaching Staff in Private Colleges and Universities}

In order to run the school well, it is not only possible to rely on the teacher resources described above, but also to ensure that the structure of its teaching staff is increasingly rationalized. Therefore, this requires universities and colleges to continue to increase the introduction of talents while developing. For those talented people with high academic qualifications, high qualifications, and high professional titles, they must intensify their efforts to recruit. For private schools, it is necessary to continuously accumulate and expand the self-employed teaching staff, attract outstanding graduates from some key universities, and hire high-title talents. Through these methods, the construction of the high-level talent team within the college's teacher team is accelerated. In addition, some flexible appointment mechanisms have been established in the college to ensure that construction projects of talent teams can be guaranteed.

Not only do we need to start from the perspective of Zhuang's masters, we can also continue to provide outstanding talents for frontline teachers by deepening the personnel system and establishing an efficient management system. For example, private institutions of higher learning can ensure the openness and transparency of the election system through open recruitment of cadres. This way the selected talents are more conducive to optimizing the structure of talents and provide 
strong support for the long-term development of private institutions of higher learning.

For non-government institutions of higher learning, the general teaching method is "mushio", and the system can greatly enhance teachers' professionalism. Apart from this cultivation method, schools can occasionally hold high-quality class contests, class competitions, experience exchanges, and teaching inspections. This helps young teachers to improve their basic teaching skills as quickly as possible. Level. In addition, due to the fact that higher civilian-run colleges and universities mainly cultivate talents for practical operation, it is very important for teachers to increase training for "dual-qualified" teachers. Therefore, schools need to encourage young teachers to actively participate in academic exchange meetings, participate in some related seminars or training from time to time, and constantly help them deepen their knowledge. It is also possible to use the teachers to practice practice during the summer and winter vacations. This will not only enhance their hands-on ability, but also enhance their experience to a certain extent.

For private institutions of higher learning, it is necessary to consistently focus on teaching, further improve the teaching quality monitoring system, give full play to the role of the teaching quality monitoring system, and improve the self-motivation mechanism based on the data obtained from monitoring. And from time to time, it is necessary to hold student's teaching evaluation work, and it is necessary to link with the performance evaluation of teachers and establish a fair, fair and open teaching competition system with clear penalties. Through the improvement of the school's incentive mechanism, privately-funded institutions of higher learning generally have comparable salary and treatment to public schools. This is supplemented by a relatively complete incentive mechanism that allows teachers to seriously study, conduct practical research, and stabilize the teaching staff. Nature may have to improve.

Private colleges and universities in the promotion of the quality of teaching staff, but also to do a good job of maintaining the teaching staff. and so. Private institutions of higher learning need to conscientiously do a good job in the determination of teacher qualifications, personnel agency, job title assessment, and social insurance. Private colleges and universities need to pay more attention to teachers' self-interest, improve and care about teachers' living conditions, solve teacher's worries in life, and ensure that teachers can spend their minds on how to improve the quality of teaching, so that they can retain their careers and pay for themselves. This, to a certain extent, also guarantees the stability of the teaching staff.

\section{Conclusion}

To sum up, although private colleges and universities have already undergone a qualitative leap forward and development, there are still certain problems in the process of development. How to solve is an important issue that private colleges and universities need to consider in the process of development. problem. For private colleges and universities, the construction of the teaching staff is a long-term and difficult task. It not only needs the recognition of the social environment, but also requires all the school staff to work together. Private colleges and universities also need to improve their internal recycling mechanism and ensure that all departments work together to ensure the smooth implementation of internal mechanisms. As a private college, it is necessary to assess the situation and face up to the weaknesses in the teaching staff, and take corresponding countermeasures and measures accordingly. Continuously strengthen the construction and management of the faculty, and create a contingent of teachers with excellent business, high quality, and high teaching standards.

\section{References}

[1] Liu Ying. Thoughts on the Development of Professional Teachers in Private Colleges and Universities [J]. Journal of Jilin RTV University.2017(08)

[2] Mao Xiaoju, Tang Yi. Existing problems and countermeasures in the construction of teaching staff in the transition period of private colleges and universities[J]. Curriculum Education Research. 
2016(06)

[3] Luo Mingli; Lu Shengyong. Problems and Countermeasures of Teacher Management in Private Colleges and Universities [J]. Examination Weekly. 2017 (91) 